\title{
Dihydroartemisinin Increases the Sensitivity of Photodynamic Therapy Via NF-kB/HIF-1 $\alpha /$ VEGF Pathway in Esophageal Cancer Cell in vitro and in vivo
}

\author{
Yanjing Lia Hong Sui ${ }^{a}$ Cailing Jiang ${ }^{b}$ Shumin $\mathrm{Li}^{\mathrm{a}} \quad \mathrm{Yu} \mathrm{Han^{ \textrm {a } }}$ \\ Peng Huang $^{a}$ Xiaoxue Du ${ }^{a}$ Jingwen Du ${ }^{a}$ Yuxian Baia \\ aDepartment of Gastrointestinal Oncology, Harbin Medical University Cancer Hospital, Harbin, ${ }^{\mathrm{b} T h e}$ \\ Oncology Department, The Affiliated Hospital of Guilin Medical University, Guilin, China
}

\section{Key Words}

Dihydroartemisinin • Photodynamic therapy $•$ Esophageal cancer $・ N F-k B \cdot H I F-1 \alpha \cdot V E G F$

\begin{abstract}
Background/Aims: Although photodynamic therapy (PDT) can relieve esophageal obstruction and prolong survival time of patients with esophageal cancer, it can induce nuclear factor-kappa $\mathrm{B}$ (NF-KB) activation in many cancers, which plays a negative role in PDT. Dihydroartemisinin (DHA), the most potent artemisinin derivative, can enhance the effect of PDT on esophageal cancer cells. However, the mechanism is still unclear. Methods: We generated stable cell lines expressing the super-repressor form of the NF-KB inhibitor IkB $\alpha$ and cell lines with lentivirus vector-mediated silencing of the HIF-1 $\alpha$ gene. Esophageal xenograft tumors were created by subcutaneous injection of Eca109 cells into BALB/c nude mice. Four treatment groups were analyzed: a control group, photosensitizer alone group, light alone group, and PDT group. NF-KB expression was detected by an electrophoretic mobility shift assay, hypoxiainducible factor $\alpha$ (HIF-1 $\alpha$ ) and vascular endothelial growth factor (VEGF) by real-time PCR, NF-KB, HIF- $1 \alpha$, and VEGF protein by western blot, and Ki-67, HIF-1 $\alpha$, VEGF, and NF- $\mathrm{kB}$ protein by immunohistochemistry.Results: PDT increased NF-KB activity and the gene expression of HIF- $1 \alpha$ and VEGF in vitro and in vivo. In contrast, the DHA groups, particularly the combined DHA and PDT treatment group, abolished the effect. The combined treatment significantly inhibited tumor growth in vitro and in vivo. NF-KB activity and HIF-1 $\alpha$ expression were also reduced in the stable IкB $\alpha$ expression group, whereas the former showed no change in HIF$1 \alpha$-silenced cells. Conclusion: DHA might increase the sensitivity of esophageal cancer cells to PDT by inhibiting the NF-kB/HIF-1 $\alpha /$ VEGF pathway.

Y. Li and H. Sui contributed equally to this work.

\begin{tabular}{ll}
\hline Yuxian Bai & Department of Gastrointestinal Oncology, Harbin Medical University Cancer Hospital \\
& 150 Haping St, Nangang District, Harbin, Heilongjiang 150081 (China) \\
& Tel. +86-451-86298303; Fax +86-451-86298961; E-Mail bai_yuxian@126.com
\end{tabular}




\section{Cellular Physiology Cell Physiol Biochem 2018;48:2035-2045

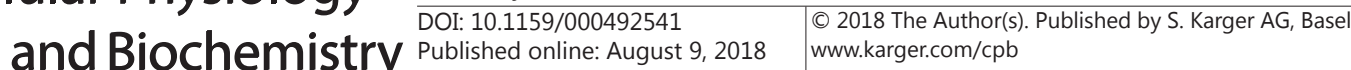 \\ Li et al.: Dihydroartemisinin Potentiates Anti-Tumor Effects of Photodynamic Therapy}

\section{Introduction}

Esophageal cancer is the eighth most common cause of cancer worldwide and the fourth leading cause of all cancer deaths in China [1, 2]. Many patients with advanced esophageal cancer have dysphagia and weakness due to incomplete obstruction. Conventional treatments such as radiation and chemotherapy have considerable adverse effects and limited effectiveness, which result in poor survival. Therefore, a new strategy is required to prolong the survival of patients with esophageal cancer.

Photodynamic therapy (PDT) has made remarkable achievements in the treatment of benign diseases and malignant tumors since clinical research began. PDT, via a photosensitizer and visible light of the appropriate wavelength, results in the production of reactive oxygen species that destroy tumors and produce photochemical effects in the target area [3]. In particular, PDT is effective in relieving esophageal obstruction during the treatment of esophageal cancer patients. It also effectively improves quality of life and prolongs survival $[4,5]$. Accordingly, PDT is widely used in many countries. In China, PDT is approved for esophageal cancer with porfimer sodium followed by $630 \mathrm{~nm}$ wavelength excimer dye laser irradiation. A retrospective analysis of 90 Chinese esophageal cancer patients who underwent PDT, PDT combined with chemotherapy, or chemotherapy alone reported that PDT combined with chemotherapy was superior to PDT alone and chemotherapy alone for advanced esophageal cancer [6]. An international study investigated the 5-year efficacy and safety of PDT with Photofrin (PHOPDT) for Barrett's high-grade dysplasia; 208 patients were enrolled from 30 sites in 4 countries. This trial showed that PHOPDT is a clinically and statistically effective therapy for long-term ablation of high-grade dysplasia that reduces the potential impact of cancer compared with omeprazole alone [7]. Thus, PDT is becoming increasingly accepted as an alternative therapy for esophageal cancer.

Activation of nuclear factor-kappa B (NF- $\mathrm{kB}$ ) can be induced by many photosensitizermediated types of PDT [8]. Additionally, NF- $\mathrm{BB}$ inhibition improves the sensitivity of tumor cells to PDT [9]. Furthermore, PDT can upregulate the expression of hypoxia-inducible factor $\alpha$ (HIF-1 $\alpha$ ) and vascular endothelial growth factor (VEGF), resulting in tumor vascularization, and Kwon et al. found that NF- $\mathrm{BB}$ activation was related to the expression of HIF- $1 \alpha$ and VEGF [10]. In addition, some researchers found that inactivation of NF- $\kappa B$ could downregulate the expression of HIF-1 $\alpha$ and VEGF in gastric cancer cell lines and in a nude mouse transplantation model. They suggested that HIF-1 $\alpha$ was a downstream target of NF$\kappa \mathrm{B}$ in the gastric cancer vascularization pathway [11].

Dihydroartemisinin (DHA), which is the most potent artemisinin derivatives, has anticancer activity in solid cancers such as pancreatic cancer [12] and head and neck carcinoma [13]. In our previous studies, we showed that DHA augments PDT-induced growth inhibition and apoptosis in esophageal cancer cells and that inactivation of NF- $\kappa B$ activity is a potential mechanism [14].

Based on the above results, we supposed that PDT might improve tumor growth via the NF- $\kappa B$ / HIF-1 $\alpha$ / VEGF pathway and that DHA might enhance the sensitivity of cancer cells to PDT by inhibiting this pathway. We examined this hypothesis using both in vitro and in vivo approaches, such as electrophoretic mobility shift assay (EMSA) and real-time PCR.

\section{Materials and Methods}

\section{Materials}

Inhibitor of $\kappa \mathrm{B}$ alpha $(\mathrm{I} \kappa \mathrm{B} \alpha)$ and HIF-1 $\alpha$ small interfering RNA (siRNA) viral solutions were obtained from Shanghai Jikai Gene Chemical Technology (Shanghai, Chnia). DHA (Sigma-Aldrich, St. Louis, MO) was dissolved in dimethyl sulfoxide (Sigma-Aldrich) and stored at $-20^{\circ} \mathrm{C}$. 5- Aminolevulinic (ALA) was reconstituted in RPMI 1640 medium and stored at $-20^{\circ} \mathrm{C}$. Antibodies against Ki67, HIF- $1 \alpha$, and VEGF were purchased from Abcam (Cambridge, UK) and antibody against NF- $\kappa$ B p65 was purchased from Cell Signaling 


\section{Cellular Physiology Cell Physiol Biochem 2018;48:2035-2045

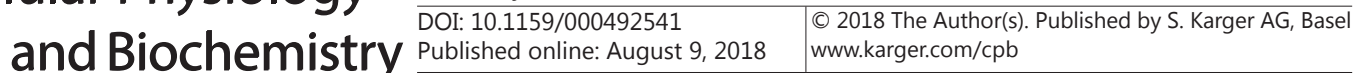 \\ Li et al.: Dihydroartemisinin Potentiates Anti-Tumor Effects of Photodynamic \\ Therapy}

Technology (Danvers, MA). Horseradish peroxidase-conjugated secondary antibodies were obtained from Beijing Zhongshan Golden Bridge Biotechnology (Beijing, China), and $\beta$-actin was obtained from Santa Cruz Biotechnology (Santa Cruz, CA).

\section{Cells and lentiviral transfection}

The human esophageal cancer cell line Eca109 (Laboratory of Medical Genetics, Department of Biology, Harbin Medical University, Harbin, China) was grown in RPMI 1640 medium containing 10\% heatinactivated fetal bovine serum (FBS) and $100 \mathrm{U} / \mathrm{ml}$ penicillin/streptomycin. Cells were maintained in a humidified atmosphere of $5 \% \mathrm{CO} 2$ at $37^{\circ} \mathrm{C}$. Once cells reached confluence, they were subcultured using trypsin digestion. Cells in the logarithmic phase were selected for experiments. The lentiviral transfection protocol was conducted in accordance with the manufacturer's recommendations.

\section{Nude mice}

All animal handling was carried out in accordance with the National Institute of Health Guide for the Care and Use of Laboratory Animals (1996 revision) and was conducted with the permission of the ethics committee of our institution. Forty 3-4-week-old female nude mice weighing 18-20 g were obtained from Shanghai Slyke Animal Research Center. Tumors were established by subcutaneous injection of $5 \times 106$ Eca109 cells into the flanks of the mice. When tumors reached around $25 \mathrm{~mm} 3$ in size (at about 7 days), the mice were randomly assigned to 10 groups ( 4 animals in each group): control, 5-ALA alone, light alone, PDT, control for HIF- $1 \alpha$ silencing, HIF- $1 \alpha$-silenced, control for stable expression of I $\mathrm{IB} \alpha$, stable expression of IKB $\alpha$, DHA, and PDT + DHA. The mice were closely monitored. Tumor size was measured every other day with calipers and tumor volume was calculated according to the formula: $\pi / 6 \times$ largest diameter $\times$ (smallest diameter)2. About 2 weeks later, the mice were euthanized, and the tumors were removed and frozen in $-80^{\circ} \mathrm{C}$ or fixed with $10 \%$ paraformaldehyde.

\section{PDT treatment}

Eca109 cells were incubated in 96-well or 6-well flat-bottomed microplates, and the supernatants were removed and replaced with $200 \mu \mathrm{l}$ of fresh FBS-free medium. The cells were then treated with 5-ALA (5-aminolevulinate acid) $(0.1-1.0 \mathrm{mmol} / \mathrm{L}$ ) for $4 \mathrm{~h}$. Prior to irradiation, the cells were washed three times with phosphate-buffered saline (PBS) and another $200 \mu \mathrm{l}$ of RPMI 1640 was added before illumination. Irradiation was carried out using a 630-nm wavelength Diomed 630 PDT system (Diomed Inc., UK) at a fluence rate of $25 \mathrm{~W} / \mathrm{cm} 2$. After irradiation, the medium was replaced with RPMI 1640 containing $10 \%$ FBS with and without various concentrations of DHA.

\section{Real-time PCR}

Total RNA was isolated from cell lines and frozen tissue obtained from resected specimens using an RNeasy Mini Kit (Qiagen, Hilden, Germany). Single-stranded cDNA was synthesized from $1.0 \mathrm{mg}$ of total RNA using a SuperScript ${ }^{\circledR}$ VILO cDNA synthesis kit and Master Mix (Thermo Fisher Scientific Inc., Waltham, MA). Quantitative real-time PCR (RT-PCR) was performed using TaqMan ${ }^{\circledR}$ Gene Expression Assays and a Step One Plus Real-Time PCR instrument (Thermo Fisher Scientific Inc.).

\section{Western blot analysis}

Eca109 cells $(2 \times 105$ cells/well $)$ were grown in 6-well plates and cultured overnight to allow for cell attachment. After the designated treatment $24 \mathrm{~h}$ later, whole-cell lysates were prepared using RIPA buffer (Beyotime Institute of Biotechnology, Jiangsu, China). Total protein samples were centrifuged at $14000 \mathrm{rpm}$ for $10 \mathrm{~min}$ at $4{ }^{\circ} \mathrm{C}$ and then quantified using the Bradford assay. The protein contents of the cell homogenates were determined, and samples containing $30 \mu \mathrm{g}$ total protein were resolved on $12 \%$ polyacrylamide sodium dodecyl sulfate gels and blotted onto polyvinylidene difluoride membranes. The membranes were blocked with $5 \%$ nonfat milk and incubated overnight at $4^{\circ} \mathrm{C}$ with primary antibodies. After 30 -min washes in wash buffer, the membranes were incubated with the appropriate horseradish-conjugated secondary antibody for $1 \mathrm{~h}$ at room temperature. The blots were visualized using a chemiluminescence detection kit (ECL-PLUS; HaiGene, Harbin), and anti- $\beta$-actin was used to ensure equal loading.

\section{KARGER}




\section{Cellular Physiology Cell Physiol Biochem 2018;48:2035-2045 \begin{tabular}{ll|l} 
and Biochemistry Published onlIne: August 9, 2018 & $\begin{array}{l}\text { (c) } 2018 \text { The Author(s). Published by S. Karger AG, Basel } \\
\text { www.karger.com/cpb }\end{array}$
\end{tabular} \\ Li et al.: Dihydroartemisinin Potentiates Anti-Tumor Effects of Photodynamic \\ Therapy}

EMSA

Eca109 cells $(2 \times 105$ cells/well) were grown in 6-well plates and cultured overnight to allow for cell attachment. After the designated treatment $24 \mathrm{~h}$ later, the cells were washed three times in cold PBS, scraped in cold PBS, and centrifuged at $5000 \mathrm{rpm}$ for $5 \mathrm{~min}$. The nuclear protein fraction was obtained using a nuclear extraction kit (Thermo Fisher Scientific, Inc.), and protein concentrations were measured using a BCA protein assay (Thermo Fisher Scientific, Inc.). The EMSA binding reaction was performed using an EMSA/Gel-Shift kit (Thermo Fisher Scientific, Inc.), and DNA-protein complexes were resolved by $3 \mathrm{~h}$ electrophoresis in native $6 \%$ polyacrylamide gels at $200 \mathrm{~V}$ using $0.25 \mathrm{~mol} / \mathrm{L} \mathrm{Na}$ borate, $0.5 \mathrm{mmol} / \mathrm{L}$ EDTA, and $0.25 \mathrm{~mol} / \mathrm{L}$ Tris, $\mathrm{pH}$ 8.0. The gels were vacuum-dried and exposed to Fuji X-ray film at $-80^{\circ} \mathrm{C}$ for 16 to $25 \mathrm{~h}$. The sequences of the probes used here were according to a previous study [14] wild-type NF- $\kappa \mathrm{B}$, 5'-GGTTACAAGGGACTTTCCGCTG-3', and mutant NF- $\kappa B$, 5'-GGTTAACAACTCACTTTCCGCCTG-3'. The dried gels were visualized using CoolImager (IMGR002), and radioactive bands were quantified using Scion Image software (Scion Corp., Frederick, MD).

\section{Immunohistochemistry}

Immunohistochemical analysis was performed using the Two-Step IHC Detection Reagent (PV-6001) kit according to the manufacturer's instructions. Paraffin-embedded tissue blocks containing xenograft specimens were cut in a microtome $(\sim 4 \mu \mathrm{m}$ thick). In brief, tissue sections were deparaffinized in xylene and rehydrated in a series of graded alcohol solutions according to standard procedures. The sections were then immersed in 3\% hydrogen peroxide for $10 \mathrm{~min}$ to quench endogenous peroxidase. Antigen retrieval was performed for $3 \mathrm{~min}$ in a pressure cooker containing $10 \mathrm{mM}$ citrate buffer (pH 6.0) to enhance immunoreactivity. The slides were then incubated with primary antibody at $4^{\circ} \mathrm{C}$ overnight. After PBS washes, rabbit secondary antibody was applied for $20 \mathrm{~min}$ at room temperature. Color was developed using 3, 3'-diaminobenzidine tetrahydrochloride (Dako, Hamburg, Germany). The slides were then counterstained with Meyer's hematoxylin and dehydrated in ethanol. Finally, the slides were mounted and coverslipped with Resina. The negative control slides were stained with rabbit serum instead of antibodies. All tissue sections were analyzed by two independent pathologists experienced in immunohistochemical evaluation.

\section{Statistical analysis}

All results are expressed as the mean \pm standard deviation, except for the results from the western blot assay. One-way ANOVA was used for statistical analysis. A P-value of less than 0.05 indicated statistical significance.

\section{Results}

PDT increases $N F-\kappa B$ activity in vitro

As shown in Fig. 1A, PDT significantly increased the activity of NF- $\mathrm{KB}$ compared with the control group (P $<0.05$ ). However, the NF$\kappa \mathrm{B}$ activity was reduced in the stable I $\mathrm{KB} \alpha$ expression group, whereas there was no change in the HIF- $1 \alpha$ silenced group exposed to PDT. In accordance with our previous studies, DHA significantly abrogated the ability of PDT to induce NF$\kappa B$ activation $(P<0.05$, Fig. 1B).

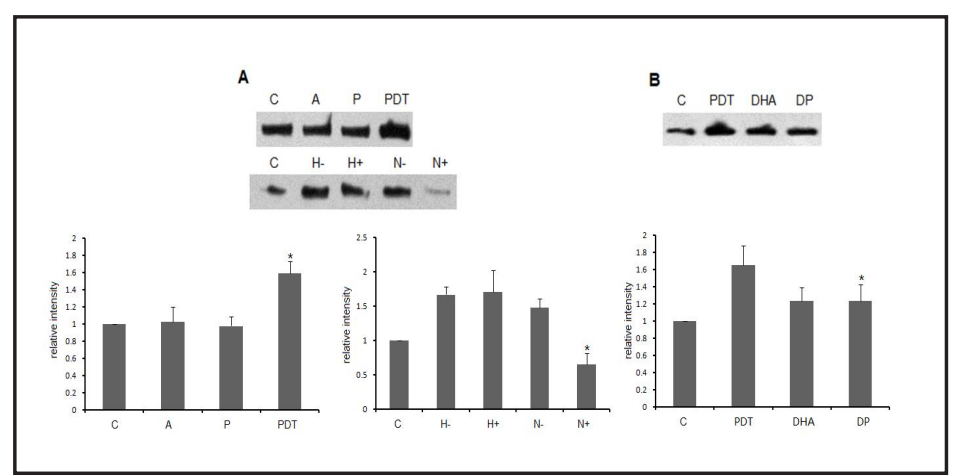

Fig. 1. EMSA of NF- $\kappa B$ DNA-binding activity in nuclear extracts in vitro. (A) PDT clearly increased the activity of NF- $\kappa$ B. (B) DHA significantly abrogated the inductive effect of PDT on NF- $\kappa$ B activation. Densitometric quantification of the data presented in the top panel. ${ }^{*} \mathrm{P}<0.05$ compared with the control group. Note: control (C), 5-ALA treatment (A), single phototherapy (P), PDT single treatment (PDT), control for HIF-1 $\alpha$ silencing (H-), HIF-1 $\alpha$-silenced $(\mathrm{H}+)$, stable I $\kappa \mathrm{B} \alpha$ expression control $(\mathrm{N}-)$, stable $\mathrm{I} \kappa \mathrm{B} \alpha$ expression $(\mathrm{N}+)$, DHA single treatment (DHA), PDT and DHA combined treatment (DP).

\section{KARGER}




\section{Cellular Physiology and Biochemistry

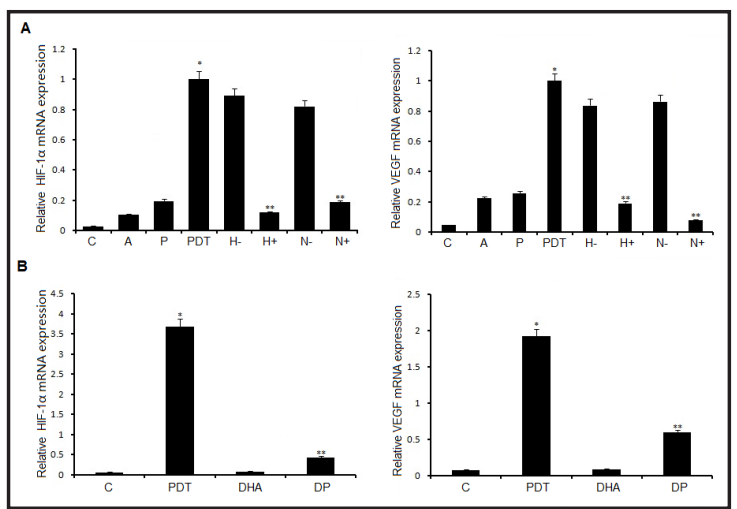

Fig. 2. RT-PCR for expression of HIF-1 $\alpha$ and VEGF. (A) PDT increased the expression of HIF- $1 \alpha$ and VEGF. (B) Combined PDT and DHA treatment notably reduced the expression of HIF- $1 \alpha$ and VEGF. Note: control (C), 5-ALA treatment (A), single phototherapy (P), PDT single treatment (PDT), control for HIF-1 $\alpha$ silencing $(\mathrm{H}-)$, HIF- $1 \alpha$-silenced $(\mathrm{H}+)$, stable I $\mathrm{BB} \alpha$ expression control $(\mathrm{N}-)$, stable I $\kappa \mathrm{B} \alpha$ expression $(\mathrm{N}+)$, DHA single treatment (DHA), PDT and DHA combined treatment (DP). ${ }^{*} \mathrm{P}<0.05,{ }^{* *} \mathrm{P}<0.01$.

PDT increases the gene expression of HIF$1 \alpha$ and VEGF in vitro

As shown in Fig. 2A, the expression levels of both HIF- $1 \alpha$ and VEGF were significantly higher in the PDT group than in the control group $(\mathrm{P}<0.05)$. However, their expression levels were clearly reduced in the HIF- $1 \alpha$-silenced and stable I $\kappa \mathrm{B} \alpha$ expression groups exposed to PDT $(\mathrm{P}<0.05)$. Furthermore, combined PDT and DHA treatment reduced the expression of HIF- $1 \alpha$ and VEGF compared with PDT or DHA alone (P < 0.05, Fig. 2B).

\section{PDT upregulates the expression of $p 65, H I F-1 \alpha$, and VEGF in vitro}

To further verify the effect of PDT on HIF- $1 \alpha$ and VEGF, the expression of related proteins was examined by western blotting. As shown in Fig. 3A, cells treated with PDT had markedly higher expression of p65, HIF-1 $\alpha$, and VEGF than the control group. In contrast, the expression levels of HIF- $1 \alpha$ and VEGF were clearly downregulated in HIF- $1 \alpha$-silenced

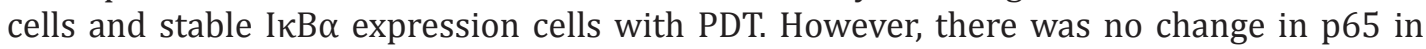
HIF-1 $\alpha$-silenced cells. Furthermore, combined PDT and DHA treatment notably reduced the expression of p65, HIF-1 $\alpha$, and VEGF compared with PDT or DHA alone (Fig. 3B).

\section{PDT inhibits tumor growth}

PDT clearly inhibited tumor growth compared with the control group; this inhibition was more significant in HIF- $1 \alpha$-silenced and stable IkB $\alpha$ expression groups $(\mathrm{P}<0.05$, Fig. $4 \mathrm{~A})$. Furthermore, combined PDT and DHA treatment inhibited tumor growth more than DHA or PDT alone ( $\mathrm{P}<0.05$, Fig. 4B).

\section{PDT increases NF- $\kappa B$ activity in vivo}

As shown in Fig. 5A, PDT increased the activity of NF- $\kappa B$ compared with the control group $(\mathrm{P}<0.05)$. Nevertheless, the activity of NF- $\kappa \mathrm{B}$ was clearly reduced in the stable I $\kappa \mathrm{B} \alpha$ 
Li et al.: Dihydroartemisinin Potentiates Anti-Tumor Effects of Photodynamic

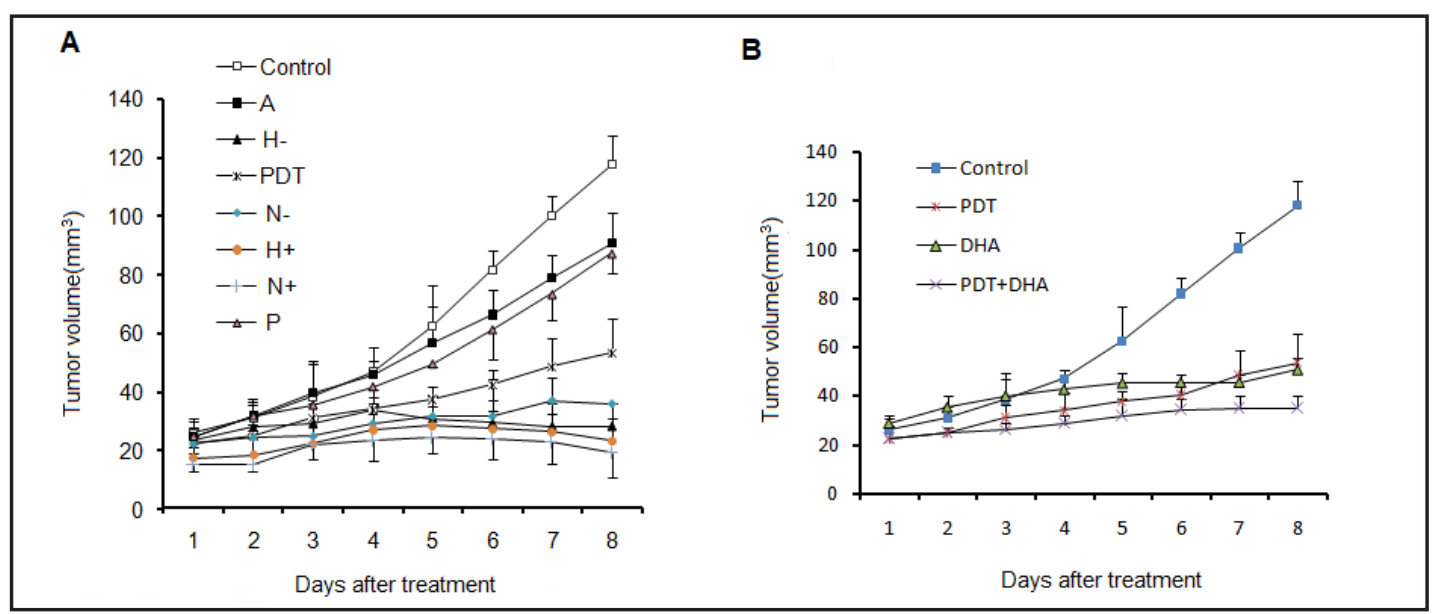

Fig. 4. Tumor growth curve. (A) PDT clearly inhibited tumor growth compared with the control group. (B) Combined PDT and DHA treatment more greatly inhibited tumor growth than DHA or PDT alone. Note: control (C), 5-ALA treatment (A), single phototherapy (P), PDT single treatment (PDT), control for HIF-1 $\alpha$ silencing ( $\left.\mathrm{H}^{-}\right)$, HIF- $1 \alpha$-silenced $(\mathrm{H}+)$, stable I $\mathrm{B} \alpha$ expression control $(\mathrm{N}-)$, stable I $\kappa \mathrm{B} \alpha$ expression $(\mathrm{N}+)$, DHA single treatment (DHA), PDT and DHA combined treatment (DP).

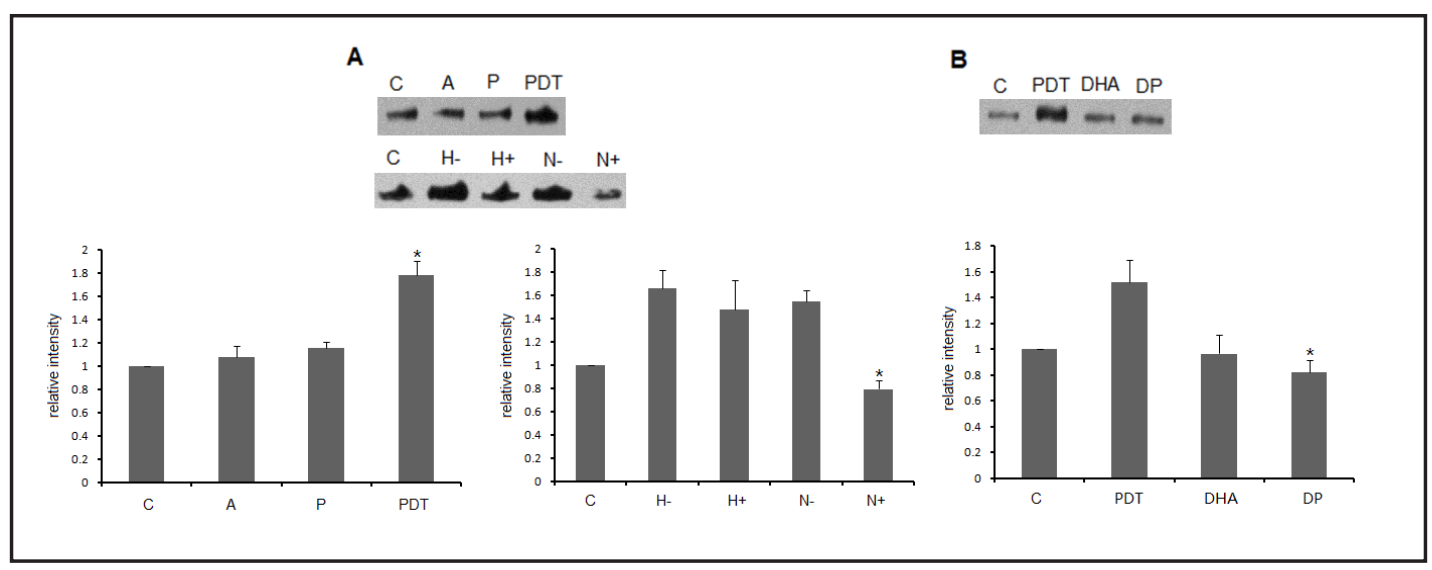

Fig. 5. EMSA of NF- $\kappa B$ DNA-binding activity in nuclear extracts in vivo. (A) PDT clearly increased the activity of NF- $\kappa$ B. (B) DHA significantly abrogated the inductive effect of PDT on NF- $\kappa$ B activation. Densitometric quantification of the data presented in the top panel. ${ }^{*} \mathrm{P}<0.05$ compared with the control group. Note: control (C), 5-ALA treatment (A), single phototherapy (P), PDT single treatment (PDT), control for HIF-1 $\alpha$

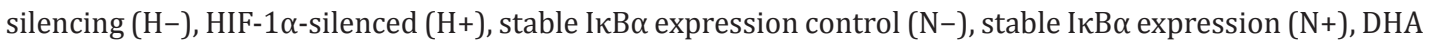
single treatment (DHA), PDT and DHA combined treatment (DP).

expression group, whereas there was no clear change in HIF-1 $\alpha$-silenced cells. Similarly, combined PDT and DHA treatment significantly inhibited the activity of NF- $\kappa$ B compared with PDT or DHA alone (P $<0.05$, Fig. 5B).

Combined PDT and DHA treatment decreases the gene expression of HIF-1 $\alpha$ and VEGF in vivo

The expression levels of the HIF- $1 \alpha$ and VEGF genes were assessed with RT-PCR. As shown in Fig. 6, combined PDT and DHA treatment significantly inhibited the expression of the HIF-1 $\alpha$ and VEGF gene compared with PDT alone (P < 0.05, Fig. 6). 


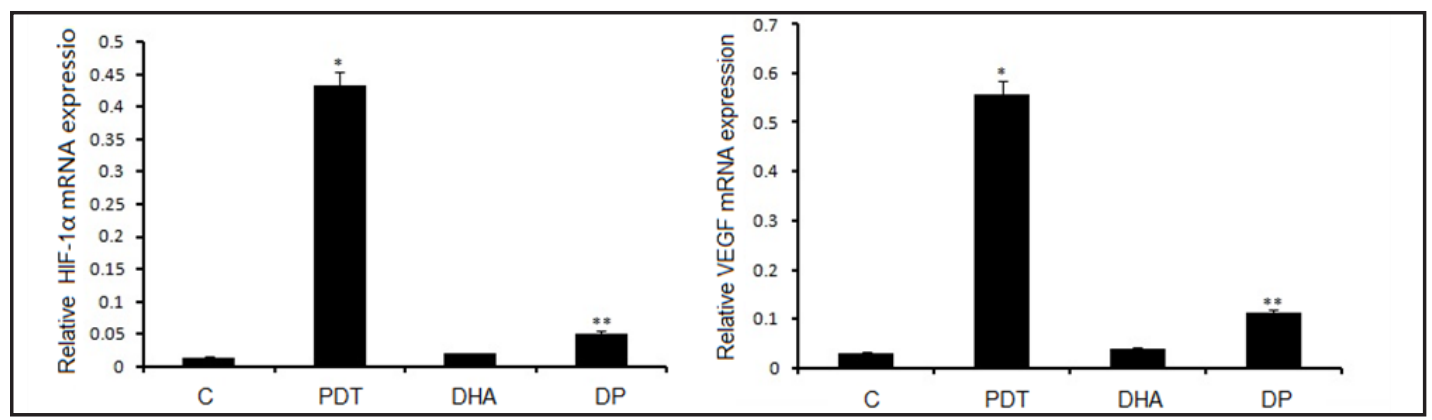

Fig. 6. RT-PCR for expression of HIF- $1 \alpha$ and VEGF. Combined PDT and DHA treatment notably reduced the expression of HIF- $1 \alpha$ and VEGF. Note: control (C), PDT single treatment (PDT), DHA single treatment (DHA), PDT and DHA combined treatment (DP).

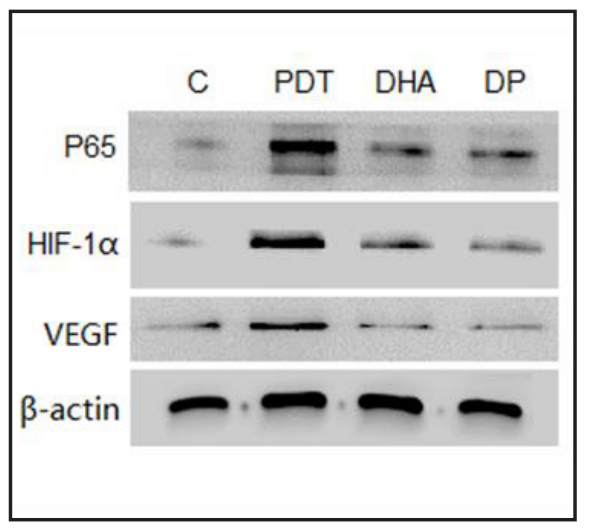

Fig. 7. Western blotting for expression of p65, HIF-1 $\alpha$, and VEGF protein in vivo. Combined PDT and DHA treatment notably reduced the expression of p65, HIF- $1 \alpha$, and VEGF. Note: control (C), PDT single treatment (PDT), DHA single treatment (DHA), PDT and DHA combined treatment (DP).

\section{Combined PDT and DHA treatment downregulates the expression of $p 65, H I F-1 \alpha$, and VEGF in vivo}

As above, western blotting was used to test the expression of p65, HIF- $1 \alpha$, and VEGF. The results revealed that combined PDT and DHA treatment clearly decreased the expression of p65, HIF-1 $\alpha$, and VEGF compared with PDT alone (Fig. 7).

\section{Combined PDT and DHA} treatment inhibits the expression of $K i-67, N F-\kappa B, H I F-1 \alpha$, and VEGF protein in vivo

Immunohistochemistry was used to detect the expression levels of proteins. Combined PDT and DHA treatment downregulated the expression of Ki-67, NF- $\kappa B, H I F-1 \alpha$, and VEGF compared with the control group (Fig. 8).

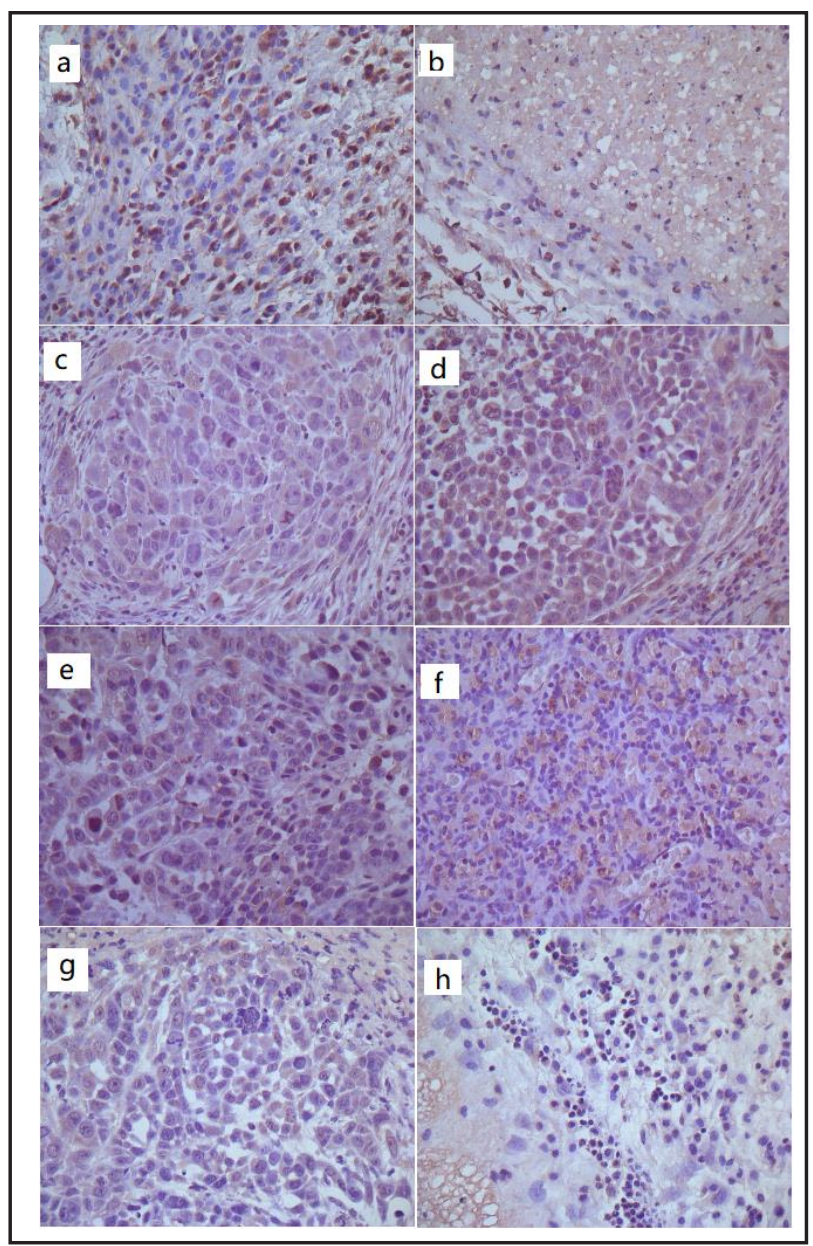

Fig. 8. Immunohistochemical expression of Ki67, NF- $\kappa B$, HIF- $1 \alpha$, and VEGF. Combined PDT and DHA treatment downregulated the expression of Ki-67 (control, a; combined treatment, b), NF- $\mathrm{KB}$ (control, c; combined treatment, d), HIF-1 $\alpha$ (control, e; combined treatment, f), and VEGF (control, g; combined treatment, h).

\section{KARGER}




\section{Cellular Physiology Cell Physiol Biochem 2018;48:2035-2045 \begin{tabular}{l|l|l} 
and Biochemistry Published onIne: August 9, 2018 & $\begin{array}{l}\text { (c) } 2018 \text { The Author(s). Published by S. Karger AG, Basel } \\
\text { www.karger.com/cpb }\end{array}$
\end{tabular} \\ Li et al.: Dihydroartemisinin Potentiates Anti-Tumor Effects of Photodynamic \\ Therapy}

\section{Discussion}

In the present study and our previous studies, we found that 5- ALA-PDT induced cell apoptosis and reduced cell viability in esophageal cancer cells in vitro and in vivo [14]. In this study, we further investigated the effect of 5-ALA-PDT on the expression of NF- $\kappa \mathrm{B}$, HIF$1 \alpha$, and VEGF in esophageal cancer cells as well as the possible molecular mechanisms. Esophageal cancer has high morbidity and mortality, partly because patients tend to be diagnosed at an advanced stage and with esophageal obstruction, which seriously affects their quality of life. Thankfully, an effective medical treatment, PDT, has been found to relieve the esophageal obstruction by inducing localized tumor destruction via the photochemical generation of cytotoxic singlet oxygen [15-19].

$\mathrm{NF}-\kappa \mathrm{B}$ is a critical transcription factor that regulates various cell processes, including embryonic development, immunity, apoptosis, angiogenesis, and proliferation [20]. Prior to activation, NF- $\mathrm{KB}$ protein is predominantly restricted to the cytosol by associating with members of the I $\kappa$ f family. Phosphorylation of I $\kappa$ B by I $\kappa B$ kinases triggers the degradation of I $\kappa B$ and allows the translocation of NF- $\kappa B$ to the nucleus. In the present study, as determined using EMSA, PDT activated NF- $\kappa \mathrm{B}$ in esophageal cancer cells in vitro and in vivo. However, DHA significantly abrogated the inductive effects of PDT on NF- $\mathrm{KB}$ activation. The activation of NF-KB induced by PDT was first found by Ryter et al. in their study on the Photofrinmediated PDT treatment of leukemia in 1993 [21]. Researchers have subsequently found this phenomenon in PDT mediated by other photosensitizers, such as 5-ALA and zinc phthalocyanine [22-24]. Activated NF- $\mathrm{BB}$ induced cell apoptosis through the JNK pathway in a study of Ca9-22 oral cancer cells treated with 5-ALA-PDT [22]. Broekgaarden et al. found that siRNA knockdown of NF- $\mathrm{kB}$ increased survival signaling in murine breast carcinoma (EMT6) cells and exacerbated the inflammatory response in murine RAW 264.7 macrophages. These results suggested a pro-death and immunosuppressive role of NF- $\kappa \mathrm{B}$ in PDT-treated cells [23]. However, some researchers have proposed that NF- $\kappa B$ plays a negative role in PDT treatment of tumors. Coupienne et al. found that inhibition of NF- $\kappa B$ improved the glioblastoma cell death in response to 5-ALA-PDT [9]. Our previous study also demonstrated that PDT could enhance NF- $\mathrm{\kappa B}$ activation in esophageal cancer cell lines and that inhibition of NF- $\kappa$ B activation could increase the rates of cell growth inhibition and apoptosis [14].

HIF- $1 \alpha$, as a master regulator of the transcriptional response to oxygen deprivation in cancer cells, was also induced by PDT in our study. This factor upregulates a series of genes that support the tumor cell to compensate for the hypoxic microenvironment [25]. Koukourakis et al. examined the expression of HIF- $1 \alpha$ and HIF- $2 \alpha$ in 37 early-stage esophageal cancers treated with PDT; they found that high expression of HIF- $1 \alpha$ was negatively correlated with the effects of PDT [26]. Moreover, study of the effect of 5-ALA-mediated PDT on esophageal cancer cells suggested that hypoxia-induced HIF-1 $\alpha$ overexpression attenuated PDT efficacy through both angiogenesis and possibly cellular resistance to death [27]. VEGF, a downstream target gene of HIF- $1 \alpha$, is one of the most important angiogenic proteins. Its binding to specific receptors induces proliferation and migration of vein endothelial cells, improved vascular permeability, and eventually angiogenesis [28]. Similarly, in our study, its transcriptional activity and protein expression was also higher in the PDT group than in the control group. Using a transplantable BA mouse mammary carcinoma, Ferrario et al. found that Photofrin-mediated PDT induced expression of the HIF- $1 \alpha$ subunit of the heterodimeric HIF-1 transcription factor and also increased VEGF protein levels [29]. Jiang et al. used monoclonal antibodies against VEGF on intracranial glioblastoma xenografts in nude mice and found that the antibody could significantly strengthen the effect of PDT [30]. All of these studies showed that the expression of HIF-1 $\alpha$ and VEGF could induce angiogenesis and attenuate PDT efficacy.

NF- $\kappa \mathrm{B}$ expression in tumor tissues is significantly correlated with HIF-1 $\alpha$ expression, VEGF expression, and the presence of vascular invasion [31]. Inhibitors of NF- $\kappa B$, such as BAY11-7028, can suppress HIF-1 $\alpha$ and VEGF [32]. In addition, a study of the antiangiogenic 


\section{Cellular Physiology Cell Physiol Biochem 2018;48:2035-2045 \begin{tabular}{l|l} 
DOI: 10.1159/000492541 & and Biochemistry \\
Published online: August 9, 2018 & $\begin{array}{l}\text { O 2018 The Author(s). Published by S. Karger AG, Basel } \\
\text { www.karger.com/cpb }\end{array}$
\end{tabular} \\ Li et al.: Dihydroartemisinin Potentiates Anti-Tumor Effects of Photodynamic Therapy}

effects of a novel synthetic curcumin analog in pancreatic cancer demonstrated that the curcumin analogues EF31 and UBS109, which can inhibit NF- $\mathrm{BB}$ transcription, induced the downregulation of HIF- $1 \alpha$ and VEGF in vivo [33]. Consistent with these studies, our findings confirmed that 5-ALA-PDT induced NF- $\mathrm{KB}$ activation during treatment of esophageal cancer cells, which increased the expression of the downstream proteins HIF- $1 \alpha$ and VEGF. HIF- $1 \alpha$ and VEGF were clearly downregulated in HIF- $1 \alpha$-silenced cells and stable IкB $\alpha$ expression cells. However, there was no change in p65 in HIF- $1 \alpha$-silenced cells. Combined PDT and DHA treatment notably reduced the expression of p65, HIF-1 $\alpha$, and VEGF compared with the PDT or the DHA. Therefore, we proposed the hypothesis that vascularization might be induced by PDT through the NF- $\mathrm{BB} / \mathrm{HIF}-1 \alpha /$ VEGF pathway. In our opinion, PDT induces the activation of NF- $\kappa B$, which activates HIF- $1 \alpha /$ VEGF and thereby causes vascularization. These effects support blood vessels for tumor growth and eventually impair the effect of PDT. In our study, we proved the hypothesis at the molecular, cellular, and animal levels.

Based on these results, we expect that an anti-tumor drug will be found to enhance sensitivity to PDT by suppressing tumor vascularization through the NF- $\mathrm{KB} / \mathrm{HIF}-1 \alpha / \mathrm{VEGF}$ pathway. DHA, which is the most potent artemisinin derivative, has exhibited anticancer activity in various cancers, including osteosarcoma and fibrosarcoma [12]. We previously showed that DHA might be a novel therapeutic agent for esophageal cancer [34]. In addition, some studies suggested that DHA had anti-angiogenic effects. In a study of the effect of DHA on gliomas, DHA suppressed the expression of HIF-1 $\alpha$ and VEGF due to hypoxia [35]. In our previous and present studies, we showed that DHA augments PDT-induced growth inhibition via inactivation of NF- $\kappa \mathrm{B}$ in esophageal cancer cells in vitro and in vivo. In our view, DHA has the capacity to inhibit the activation of NF- $\mathrm{BB}$ by PDT, which downregulates the expression of the angiogenic proteins HIF- $1 \alpha$ and VEGF and thereby inhibits vascularization.

\section{Conclusion}

PDT can activate the NF- $\kappa$ B/HIF-1 $\alpha /$ VEGF pathway and DHA can sensitize esophageal cancer cells to PDT by inhibiting this pathway. Further in-depth studies are required to explore the basic theory, perform drug screening and preclinical pharmacological research, and develop a clinical application. Next, we intend to investigate the mechanism of tumor vascularization of PDT.

\section{Abbreviations}

DHA (dihydroartemisinin); EMSA (electrophoretic mobility shift assay); FBS (fetal bovine serum); HIF- $1 \alpha$ (hypoxia-inducible factor $\alpha$ ); I $\kappa \mathrm{B} \alpha$ (inhibitor of $\kappa \mathrm{B}$ alpha); NF- $\kappa \mathrm{B}$ (nuclear factor-kappa B); PBS (phosphate-buffered saline); PDT (photodynamic therapy); qRT-PCR; quantitative (real-time PCR); siRNA (small interfering RNA); VEGF (vascular endothelial growth factor).

\section{Acknowledgements}

This work was supported by the Natural Science Foundation of China (81372610), the Wu Jieping Medical Foundation (320.6750.16002), the Heilongjiang Provincial Education Department Foundation (12531355), the Heilongjiang Provincial Health Department Foundation (660), and the Scientific Research Foundation of Harbin Medical University Cancer Hospital (JJZ2011-18). We are grateful to the teachers of the central cancer laboratory of Harbin Medical University for their kind help. In addition, the authors thank Yuyan Ma and Yangmei Yang for their technical assistance. 


\section{Cellular Physiology Cell Physiol Biochem 2018;48:2035-2045 \begin{tabular}{ll|l} 
and Biochemistry Published online: August 9, 2018 & $\begin{array}{l}\text { (C) } 2018 \text { The Author(s). Published by S. Karger AG, Basel } \\
\text { www.karger.com/cpb }\end{array}$
\end{tabular} \\ Li et al.: Dihydroartemisinin Potentiates Anti-Tumor Effects of Photodynamic Therapy}

\section{Disclosure Statement}

The authors declare to have no conflict of interests.

\section{References}

1 Yoshioka M, Ohashi S, Ida T, Nakai Y, Kikuchi O, Amanuma Y, Matsubara J, Yamada A, Miyamoto S, Natsuizaka M, Nakagawa H, Chiba T, Seno H, Muto M: Distinct effects of EGFR inhibitors on epithelial- and mesenchymal-like esophageal squamous cell carcinoma cells. J Exp Clin Cancer Res 2017;36:101.

-2 Wang B, Zhao B, Pang LP, Zhao YD, Guo Q, Wang JW, Zheng YC, Zhang XH, Liu Y, Liu GY, Guo WG, Wang C, Li ZH, Mao XJ, Yu B, Ma LY, Liu HM: LPE-1, an orally active pyrimidine derivative, inhibits growth and mobility of human esophageal cancers by targeting LSD1. Pharmacol Res 2017;122:66-77.

3 Muchowicz A, Wachowska M, Stachura J, Tonecka K, Gabrysiak M, Wolosz D, Pilch Z, Kilarski WW, Boon L, Klaus TJ, Golab J: Inhibition of lymphangiogenesis impairs antitumour effects of photodynamic therapy and checkpoint inhibitors in mice. Eur J Cancer 2017;83:19-27.

- Kuzyniak W, Schmidt J, Glac W, Berkholz J, Steinemann G, Hoffmann B, Ermilov EA, Gurek AG, Ahsen V, Nitzsche B, Hopfner M: Novel zinc phthalocyanine as a promising photosensitizer for photodynamic treatment of esophageal cancer. Int J Oncol 2017;50:953-963.

-5 Maas AL, Carter SL, Wileyto EP, Miller J, Yuan M, Yu G, Durham AC, Busch TM: Tumor vascular microenvironment determines responsiveness to photodynamic therapy. Cancer Res 2012;72:2079-2088. Li LB, Xie JM, Zhang XN, Chen JZ, Luo YL, Zhang LY, Luo RC: Retrospective study of photodynamic therapy vs photodynamic therapy combined with chemotherapy and chemotherapy alone on advanced esophageal cancer. Photodiagnosis Photodyn Ther 2010;7:139-143.

-7 Overholt BF, Wang KK, Burdick JS, Lightdale CJ, Kimmey M, Nava HR, Sivak MV, Jr., Nishioka N, Barr H, Marcon N, Pedrosa M, Bronner MP, Grace M, Depot M: Five-year efficacy and safety of photodynamic therapy with Photofrin in Barrett's high-grade dysplasia. Gastrointest Endosc 2007;66:460-468.

-8 Korbelik M: Complement upregulation in photodynamic therapy-treated tumors: Role of Toll-like receptor pathway and NFkappaB. Cancer Lett 2009;281:232-238.

-9 Coupienne I, Bontems S, Dewaele M, Rubio N, Habraken Y, Fulda S, Agostinis P, Piette J: NF-kappaB inhibition improves the sensitivity of human glioblastoma cells to 5-aminolevulinic acid-based photodynamic therapy. Biochem Pharmacol 2011;81:606-616.

10 Kwon HC, Kim SH, Oh SY, Lee S, Kwon KA, Lee JH, Choi HJ, Park KJ, Lee HS, Roh MS, Kim HJ: Clinicopathological significance of nuclear factor-kappa B, HIF-1 alpha, and vascular endothelial growth factor expression in stage III colorectal cancer. Cancer Sci 2010;101:1557-1561.

11 Nam SY, Ko YS, Jung J, Yoon J, Kim YH, Choi YJ, Park JW, Chang MS, Kim WH, Lee BL: A hypoxia-dependent upregulation of hypoxia-inducible factor-1 by nuclear factor-kappaB promotes gastric tumour growth and angiogenesis. Br J Cancer 2011;104:166-174.

12 Wang SJ, Gao Y, Chen H, Kong R, Jiang HC, Pan SH, Xue DB, Bai XW, Sun B: Dihydroartemisinin inactivates NF-kappaB and potentiates the anti-tumor effect of gemcitabine on pancreatic cancer both in vitro and in vivo. Cancer Lett 2010;293:99-108.

13 Lin R, Zhang Z, Chen L, Zhou Y, Zou P, Feng C, Wang L, Liang G: Dihydroartemisinin (DHA) induces ferroptosis and causes cell cycle arrest in head and neck carcinoma cells. Cancer Lett 2016;381:165-175.

14 Li YJ, Zhou JH, Du XX, Jia de X, Wu CL, Huang P, Han Y, Sui H, Wei XL, Liu L, Yuan HH, Zhang TT, Zhang WJ, Xie R, Lang XH, Liu T, Jiang CL, Wang LY, Bai YX: Dihydroartemisinin accentuates the anti-tumor effects of photodynamic therapy via inactivation of NF-kappaB in Eca109 and Ec9706 esophageal cancer cells. Cell Physiol Biochem 2014;33:1527-1536.

15 Weijer R, Clavier S, Zaal EA, Pijls MM, van Kooten RT, Vermaas K, Leen R, Jongejan A, Moerland PD, van Kampen AH, van Kuilenburg AB, Berkers CR, Lemeer S, Heger M: Multi-OMIC profiling of survival and metabolic signaling networks in cells subjected to photodynamic therapy. Cell Mol Life Sci 2017;74:11331151. 


\section{Cellular Physiology Cell Physiol Biochem 2018;48:2035-2045 \begin{tabular}{ll|l} 
and Biochemistry Published online: August 9, 2018 & $\begin{array}{l}\text { (c) } 2018 \text { The Author(s). Published by S. Karger AG, Basel } \\
\text { www.karger.com/cpb }\end{array}$
\end{tabular} \\ Li et al.: Dihydroartemisinin Potentiates Anti-Tumor Effects of Photodynamic Therapy}

16 Hsieh YJ, Wu CC, Chang CJ, Yu JS: Subcellular localization of Photofrin determines the death phenotype of human epidermoid carcinoma A431 cells triggered by photodynamic therapy: when plasma membranes are the main targets. J Cell Physiol 2003;194:363-375.

17 Khan S, Naseem I: Photocatalytic interaction of aminophylline-riboflavin leads to ROS-mediated DNA damage and cell death: A novel phototherapeutic mechanism for cancer. IUBMB Life 2017;69:611-622.

18 Solban N, Rizvi I, Hasan T: Targeted photodynamic therapy. Lasers Surg Med 2006;38:522-531.

19 Kidane B, Coughlin S, Vogt K, Malthaner R: Preoperative chemotherapy for resectable thoracic esophageal cancer. Cochrane Database Syst Rev 2015:Cd001556.

20 Xia Y, Shen S, Verma IM: NF-kappaB, an active player in human cancers. Cancer Immunol Res 2014;2:823830.

-21 Ryter SW, Gomer CJ: Nuclear factor kappa B binding activity in mouse L1210 cells following photofrin IImediated photosensitization. Photochem Photobiol 1993;58:753-756.

-22 Chen HM, Liu CM, Yang H, Chou HY, Chiang CP, Kuo MY: 5-aminolevulinic acid induce apoptosis via NFkappaB/JNK pathway in human oral cancer Ca9-22 cells. J Oral Pathol Med 2011;40:483-489.

-23 Broekgaarden M, Kos M, Jurg FA, van Beek AA, van Gulik TM, Heger M: Inhibition of NF-kappaB in Tumor Cells Exacerbates Immune Cell Activation Following Photodynamic Therapy. Int J Mol Sci 2015;16:1996019977.

24 Matroule JY, Hellin AC, Morliere P, Fabiano AS, Santus R, Merville MP, Piette J: Role of nuclear factor-kappa $\mathrm{B}$ in colon cancer cell apoptosis mediated by aminopyropheophorbide photosensitization. Photochem Photobiol 1999;70:540-548.

25 Vaupel P: The role of hypoxia-induced factors in tumor progression. Oncologist 2004;9 Suppl 5:10-17.

-26 Koukourakis MI, Giatromanolaki A, Skarlatos J, Corti L, Blandamura S, Piazza M, Gatter KC, Harris AL: Hypoxia inducible factor (HIF-1a and HIF-2a) expression in early esophageal cancer and response to photodynamic therapy and radiotherapy. Cancer Res 2001;61:1830-1832.

-27 Ji Z, Yang G, Shahzidi S, Tkacz-Stachowska K, Suo Z, Nesland JM, Peng Q: Induction of hypoxia-inducible factor-1alpha overexpression by cobalt chloride enhances cellular resistance to photodynamic therapy. Cancer Lett 2006;244:182-189.

-28 Gordon LK, Kiyohara M, Fu M, Braun J, Dhawan P, Chan A, Goodglick L, Wadehra M: EMP2 regulates angiogenesis in endometrial cancer cells through induction of VEGF. Oncogene 2013;32:5369-5376.

29 Ferrario A, von Tiehl KF, Rucker N, Schwarz MA, Gill PS, Gomer CJ: Antiangiogenic treatment enhances photodynamic therapy responsiveness in a mouse mammary carcinoma. Cancer Res 2000;60:4066-4069.

-30 Jiang F, Zhang X, Kalkanis SN, Zhang Z, Yang H, Katakowski M, Hong X, Zheng X, Zhu Z, Chopp M: Combination therapy with antiangiogenic treatment and photodynamic therapy for the nude mouse bearing U87 glioblastoma. Photochem Photobiol 2008;84:128-137.

-31 Chiche J, Pommier S, Beneteau M, Mondragon L, Meynet O, Zunino B, Mouchotte A, Verhoeyen E, Guyot M, Pages G, Mounier N, Imbert V, Colosetti P, Goncalves D, Marchetti S, Briere J, Carles M, Thieblemont C, Ricci JE: GAPDH enhances the aggressiveness and the vascularization of non-Hodgkin's B lymphomas via NFkappaB-dependent induction of HIF-1alpha. Leukemia 2015;29:1163-1176.

-32 Liang S, Chen Z, Jiang G, Zhou Y, Liu Q, Su Q, Wei W, Du J, Wang H: Activation of GPER suppresses migration and angiogenesis of triple negative breast cancer via inhibition of NF-kappaB/IL-6 signals. Cancer Lett 2017;386:12-23.

-33 Nagaraju GP, Zhu S, Ko JE, Ashritha N, Kandimalla R, Snyder JP, Shoji M, El-Rayes BF: Antiangiogenic effects of a novel synthetic curcumin analogue in pancreatic cancer. Cancer Lett 2015;357:557-565.

-34 Du XX, Li YJ, Wu CL, Zhou JH, Han Y, Sui H, Wei XL, Liu L, Huang P, Yuan HH, Zhang TT, Zhang WJ, Xie R, Lang $\mathrm{XH}$, Jia DX, Bai YX: Initiation of apoptosis, cell cycle arrest and autophagy of esophageal cancer cells by dihydroartemisinin. Biomed Pharmacother 2013;67:417-424.

-35 Huang XJ, Ma ZQ Zhang WP, Lu YB, Wei EQ: Dihydroartemisinin exerts cytotoxic effects and inhibits hypoxia inducible factor-1alpha activation in C6 glioma cells. J Pharm Pharmacol 2007;59:849-856. 